\title{
Crude oil price uncertainty and corporate carbon emissions
}

\author{
Ping Wei ${ }^{1} \cdot$ Yiying $\mathrm{Li}^{1} \cdot$ Xiaohang Ren ${ }^{1,2}$ (D) Kun Duan ${ }^{3}$
}

Received: 22 June 2021 / Accepted: 2 August 2021 / Published online: 9 August 2021

(C) The Author(s), under exclusive licence to Springer-Verlag GmbH Germany, part of Springer Nature 2021

\begin{abstract}
Low-carbon transformation has become a key priority in China, as demonstrated in the implementation of the Carbon Peak, Carbon Neutralization policy, leading to increasing concern of environmental performance at the corporate level. This paper measures the carbon emission of 1,089 Chinese companies through the EIO-LCA-based approach. Then we examine the impacts of international crude oil price fluctuations and the corporate development level on carbon emissions of individual companies. Our results indicate that an increase in international crude oil price uncertainty could inhibit the company's carbon emission. In parallel, we find that there might exist an environmental Kuznets curve (EKC) inverted U-shaped correlation between the company's development level and its environmental performance. However, some exceptions to corporate carbon performance may emerge, resulting from specific corporate characteristics such as the state-owned nature and whether the firm is listed on the stock exchange. Our results could help companies optimize their internal carbon emission structure during the low-carbon transition process and contribute to effective policy regulations towards the target of carbon reduction.
\end{abstract}

Keywords Corporate carbon emissions · Crude oil price volatility · Environmental Kuznets curve (EKC) · The EIO-LCA method

\section{Introduction}

As one of the world's major commodities and fuels, crude oil plays a vital role in the operations of the modern economic system. In particular, there is no doubt that crude oil will also affect enterprises, which are the major component that forms the system (Bildirici and Badur 2018). Meanwhile, with the increasing aggravation of climate risks, decarburization becomes a significant and urgent strategy to address the ongoing economic and environmental challenges brought about by climate change. Reducing carbon (dioxide) emissions while improving economic growth are the common goals of the lowcarbon road worldwide (Alwi et al. 2016; Li et al. 2018; Yan et al. 2019). The uniform low-carbon target has promoted stakeholders to pay increasingly large attention to the

Responsible Editor: Roula Inglesi-Lotz

Xiaohang Ren

domrxh@outlook.com

1 Business School, Central South University, Changsha 410083, China

2 School of Mathematical Sciences, University of Southampton, Southampton SO17 1BJ, UK

3 School of Economics, Huazhong University of Science and Technology, Wuhan 430074, China companies' environmental performance. Accordingly, this results in the widespread concentration of individual companies on their social responsibility performance and environment-friendly behaviours (Park et al. 2017; Ren et al. 2019; Farah et al. 2021).

So far, despite the rapid development of clean energy, the dominant position of crude oil in energy sources is still unshakable for corporates in many countries or industries and will continue to bring interferences on environmental protection (Cheng et al. 2019). In China, crude oil consumption will bring about environmental issues such as carbon emissions and sewage while driving financial growth (Zhao et al. 2019), and the sustained high demand for crude oil may lead to the uninterrupted growth of pollution (Luo et al. 2019). However, at the same time, China is firmly determined to promote the prosper of a green economy and achieve carbon neutrality. The conflict between the probable increase in carbon emissions brought about by oil consumption and the goal of "net-zero" carbon emissions urges us to wonder whether and how crude oil prices fluctuations affect the environmental performance of companies in China.

Many factors could influence the company's environmental performance, but less attention is paid to the fluctuation of oil price in the light of extant literature. The related research on the influencing factors mainly focuses on internal governance, macro-environmental regulation, pressure from 
institutional investors, and the developed degree of the region (Wang et al. 2019; Jiang et al. 2021b; Zhang et al. 2021), while there exists no direct research for the effect of oil price fluctuations on corporate environmental performance. Thus, given the urgency of the demand for low-carbon transformation and the lack of related research, we are greatly motivated to explore this research direction. Specifically, we investigate the influence of crude oil price fluctuation on the environmental performance of Chinese firms through an innovative measurement of carbon emissions of individual companies. Moreover, since corporate financial performance is known as a critical factor in determining corporate strategies, including environmental behaviours (Rahayu 2019), we further examine the influence of the economic development level of the company on its carbon emissions.

Following existing literature, the environmental performance of individual firms in this paper is represented by the carbon footprint. As researched by previous studies, the corporate environmental performance mainly includes corporate carbon emissions (Chen et al. 2017; Flammer 2021), green patents (Ooba et al. 2015; Fang et al. 2021), environmental penalties (Peng et al. 2021), corporate social responsibility reports and ESG ratings (Sabbaghi 2020; Ting 2021). Among them, carbon emission is the most concerning factor for a company's environmental performance, and therefore, it is suggested that the former one could be directly regarded as a proxy of ecological friendliness of individual firms (Fan et al. 2013; Tang and Zhang 2020; Flammer 2021).

Carbon footprint refers to the measurement of carbon emissions generated during the life cycle of products or related to activities from the life cycle perspective (Ji et al. 2011). While the carbon emission database in the USA, Europe and other regions are relatively complete (Cheng et al. 2021; Ren et al. 2021), large-scale countries and regions do not have such a professional corporate carbon emission database, including China. In the absence of data, researchers have tried several methods to gauge carbon emissions: the life cycle method (LCA), the input-output analysis method (I-O), the economic input-output life cycle method (EIO-LCA) and the calculation method in 2006 IPCC Guidelines for National Greenhouse Gas Inventories. It is documented that the EIO-LCA method can measure the carbon footprint of economic activities more comprehensively since it considers the system boundary of the supply chain and the economic input-output tables (Matthews and Small 2000; Wei and Shu 2021), and the practice of measuring urban carbon footprint, industrial carbon footprint and portfolio carbon footprint by this method has been established in China (Ji et al. 2011; Hu et al. 2017; Yu et al. 2017). Then, we have accordingly decided to select it as the measurement for the carbon footprint.

Generally speaking, crude oil price uncertainty could affect carbon performance through financial channels such as influencing production cost. This paper aims to investigate how the above two can correlate with each other. Recently, there exist numerous studies about the influence of crude oil price fluctuations on company-related variables, involving corporate investment (Phan et al. 2019; Maghyereh and Abdoh 2020), the financial performance related to corporate bonds (Shahzad et al., 2021), stock-related confidence and returns (Broadstock and Filis, 2014; Bildirici and Badur 2018). Moreover, the impact of oil price fluctuations on financial activities could also be linked with the environmental behaviour of individual firms. For example, in addition to the direct reduction in energy consumption, oil prices may also affect corporate capital expenditure. Accordingly, it may involve the disclosure of corporate carbon emissions since more capital expenditure will increase more activities related to economic appreciation and lead to an increase in the firms' carbon footprint ( $\mathrm{Li}$ et al. 2020; Karim et al. 2021).

In addition to investigating the impact of crude oil price uncertainty, this paper also researches the impact of corporate development on corporate carbon emissions. For a large economy like China, economic growth will not lead to the continuous deterioration of the environment. When the economy develops to a certain level, the negative impact on the environment will be mitigated, which impacting pattern is commonly termed as the environmental Kuznets curve (EKC) effect (Grossman and Krueger 1995; Ahmed and Long 2013; Liu et al. 2020; Adebayo 2021). Then a question comes to the fore, whether the increase in the company's scale will result in unlimited growth in carbon emissions or whether there is an inflexion point of the company development. It will lead to inhibition of corporate carbon emissions.

We are raising a research issue that no one has ever researched, to be brief, whether there is a phenomenon similar to the "EKC" inverted U-shaped effect in macroeconomic research at the company level. More so, it is clear that existing literature on the specific relationship between corporate development and carbon footprint is also sparse. We select the scale of assets as the representative of the development level of the company since it is one of the most important manifestations of a company's economic strength and plays an essential role in many aspects such as the company's development strategies and environmental performances (Zinina and Olentsova 2020; Legenchuk et al. 2020). In many corporate finance studies, it is also prevalent to quantify intangible economic impact or economic behaviour as "monetary numbers" (Borremans et al. 2018). Then, the size of assets is also often used as a proxy indicator of a company's level of development or development goals (Sari et al. 2020; Legenchuk et al. 2020).

To target our research aims, we provide an effective measurement for the company's carbon footprint and then empirically study the impact of fluctuations in crude oil prices on the company's carbon footprint. Moreover, we regard the total asset size as a representative indicator of the development level of the company and find an inverted U-shaped impact 
of the company's asset size on the carbon footprint. We confirmed that fluctuations in international oil prices and corporate assets significantly impact corporate carbon emissions and found unexpected results from corporate heterogeneity.

The contributions of this paper are discussed as follows. Firstly, this paper expands the micro-level research on the effect of crude oil-related fluctuations on the corporate level. It is the first time to examine the correlation between international oil price volatility and the carbon footprint of Chinese companies. Secondly, this paper tries to accommodate the lack of carbon emission data of Chinese companies and alleviates the practical issue that companies' energy consumption data are challenging to obtain. We attempt to measure the carbon footprint of companies from the perspective which combines the accurate calculation of industry carbon footprint and the financial performance of companies. Thirdly, this paper connects the level of corporate development with corporate environmental performance and verifies the existence of the EKC inverted U-shaped effect of corporate assets on corporate carbon emissions, which fills the research gap in this field.

The rest of this paper is arranged as follows: The "Literature review and hypothesis" section combs the literature and puts forward the core hypothesis of this paper. The "Methodology" section is the specific method used in this paper. The "Data source and empirical results" section is the data and fundamental results. The "Robust tests" section is the robustness test, and the "Conclusions" section is the conclusion.

\section{Literature review and hypothesis}

\section{Correlation between the volatility of crude oil price and corporate performance}

Crude oil is one of the leading fuel sources consumed by companies, which significantly impacts the companies' investment, stock return, and many other financial aspects. In relation to corporate investment, Wang et al. (2017a) investigated the negative effect of international oil price volatility on corporate investment in the process of China's economic emerging and transformation and validates the role of state ownership. Compared with the state-owned companies, the oil price volatility has a more significant negative impact on the corporate investment of non-state-owned companies. Chen et al. (2020) studied the influence of three typical oil shocks on corporate investment in China and found that oil demand shocks will hurt corporate investment and the enterprises in energy-related industries are more sensitive to these shocks.

At the same time, Maghyereh and Abdoh (2020) used the comprehensive data of American companies and verified that the negative impact of the uncertainty of crude oil on investment is asymmetric. The volatility of positive oil price changes reduces investment more significantly than negative changes, and the asymmetric effect is more evident in small companies. They also found that the asymmetric influence on crude oil and natural gas producers is more potent. Ilyas et al. (2021) combines oil price uncertainty with the current research hotspot, the economic policy uncertainty, and found that both above negatively impact corporate investment. More specifically, the negative effect is more pronounced in oil-producing countries. Generally speaking, the fluctuation of oil price generally harms corporate investment and will be different due to corporate heterogeneity.

On the other hand, the influence of oil price uncertainty on the corporate stock market has been studied for a long time. The stock market of many countries, such as the USA, Japan, Spain, Australia and China, has been analysed a lot. In summary, the impact of oil prices on stock returns is most likely to be significant negative in any market. The negative effect of the oil price shock on corporate shares will be slightly different in various industries. In addition, the government's relaxation of control over domestic oil prices can mitigate the harmful impact as a whole (Sadorsky 1999; Ratti and Hasan 2013; Abhyankar et al. 2013; Moya-Martínez et al. 2014; Alsalman 2016; Xiao et al. 2018). Oil prices may also indirectly affect corporate financing decisions and firms' value through lumping channels, impacting corporate capital structures such as leverage ratio or financing schemes (Haushalter et al. 2002; Fan et al. 2021).

Apart from these financial-related performances, crude oil is also closely related to the company's environmental performance. Research by Busch and Hoffmann (2007) shows that energy consumption mainly based on crude oil is the primary source of corporate carbon risk in corporate risk management. Similarly, Hoffmann and Busch (2008) pointed out that companies are the core of paving the way for a low-carbon society because most carbon-related inputs and greenhouse gases are generated from industrial production activities and carbon-based energy. Besides, crude oil is one of the most critical factors.

Allevi et al. (2019) pointed out that the environmental performance is generally improved from the following two aspects: changing the pollution level of energy production and reducing energy consumption in production. But China's dependence on oil for imported energy consumption exceeds $60 \%$, and this dependence will not decrease in the short term (Zhang et al. 2019b). To better help companies manage the carbon emissions from crude oil consumption in their business activities and the carbon risks from the use of crude oil in upstream and downstream supply chains, Greene et al. (2020) build a dynamic measurement model of carbon footprint for the whole oil transportation process, aiming to provide a more comprehensive reference for ESG management and carbon emission control of the company. 
However, relevant research has always focused on the effect of crude oil use on corporate carbon emissions. Apart from that, investigations on the effects of oil price fluctuations on carbon emissions are generally conducted for the entire macroeconomy, for example, the whole market or the whole country and region. No matter in which economy, whether in the long term or the short term, fluctuations in oil prices are significant factors affecting carbon emissions throughout the economy (Nwani 2017; Zou 2018; Musa 2020; Dong et al. 2020). In addition, energy markets such as the crude oil market will also widely affect other markets, for example, the natural gas market and the market of carbon emission trading rights (Duan et al. 2021). It will also further affect the company's consumption of other fuels and the cost of carbon emissions trading. But at the micro-level, there is no systematic in-depth study of the influence of crude oil price and its volatility on companies' carbon emissions.

From the studies mentioned above, we know that fluctuations in oil prices, especially positive fluctuations, usually have a specific inhibitory effect on corporate financial behaviour and decisions, for example, the number of capital expenditures. The decrease in economic activities such as investment may reduce carbon emission to a certain extent. More directly, the uncertainty of oil price will also affect the consumption of energies, crude oil and crude oil-derived fuels or other energies, which may also inhibit the company's carbon emission. Based on the analysis above, we propose the first hypothesis and like the following:

H1. The volatility of oil prices will significantly negatively affect corporate carbon emissions.

To further explore the influence of oil price fluctuations on corporate carbon emissions, we take some corporate heterogeneity mentioned in the literature cited into consideration. We further study and discuss the effects of corporate ownership, environmental sensitivity, whether to list or not, and the region where the companies are located in the follow-up study.

\section{The EKC hypothesis: a perspective at the corporate level}

The research on the correlation between economic growth and carbon emissions currently focuses on the traditional environmental Kuznets (EKC) curve theory. The EKC curve is proposed by Grossman and Krueger (1995) and others, who believe that the growth of a country's economy will destroy the ecological environment. When the economic level rises to a certain level, the ecological environment will not deteriorate. It will continue to recover with the development of the national economy, and the relationship between GDP and the ecological environment is in an inverted "U"-shape methodology.
Over the next 20 years, many scholars have explored the related research of the EKC curve but mainly concentrated on the comprehensive analysis of countries or regions. It is usually to study the relationship between economic growth, per capita income, socioeconomic determinants and environmental performance, and the existence of the EKC effect is confirmed in many cases (Ahmed and Long 2013; Gill et al. 2018; Aslan et al. 2018; Dogan and Inglesi-Lotz 2020; Yan et al. 2020). There are many representative environmental indicators in these studies, such as sulphide emissions and waste resources. Still, a great majority of the EKC-related literature uses carbon emissions to proxy for environmental degradation (Destek et al. 2018).

Meanwhile, research on the role of energy in the EKC effect of the economy's carbon emissions is gradually emerging. Studies have shown that we cannot completely reverse the continuous deterioration of greenhouse gases relying solely on economic growth. Under expectation, non-renewable energy such as crude oil is indeed the main factor affecting carbon emissions. Other measures such as promoting policies with renewable energy are needed to achieve the effect of turning point and reduction of greenhouse gas emissions (Zhang et al. 2017; Gill et al. 2018). For China, economic growth will undoubtedly bring about environmental improvement to a certain extent, requiring changes in energy use brought by technological innovation such as solar energy to achieve ecological friendliness. However, the current dependence on nonrenewable energy is too impregnable, so in Chinese future energy structure planning, by 2040 , electricity must surpass coal and oil to become the primary energy source in China (Jiang et al. 2021a; Sun et al. 2021).

From the previous research, we can find that, in many cases, the impact of economic development of economies on carbon emissions is presented as an inverted $U$ shape. Concerning the research conclusions of other scholars, the emergence of the EKC turning effect is mainly due to factors such as scale effect and technological progress (Lin et al. 2016; Dogan and Inglesi-Lotz 2020). The company has certain similarities with the macro-economy, such as importing and exporting raw materials and products, production activities and organizational management structure.

We compare the company to a micro-economy. The expansion period of the company is often accompanied by active and frequent production and operation activities. When the company expands to a particular scale, it has completed a certain amount of capital accumulation. On this basis, it is possible to adopt more advanced production technology or better raw materials, cleaner energy. At the same time, when the company's scale expands to a certain extent, it will also receive more investors' attention and more stringent supervision. So, whether there is a turning point in the scale of the company, and when the company develops beyond this turning point, the company's carbon emissions are reduced due to technical factors and other reasons. 
More appropriately, whether there is an EKC inverted Ushaped curve relationship between the company size and the company's carbon emissions is a difficult point to solve in this paper and an innovation point. It is conducive to enriching the relevant theory and practical experience of EKC from the micro-level and conducive to the research on the optimization strategy of corporate finance and other fields.

In response to this research problem, and combined with relevant literature, we propose the following assumptions:

H2. There is an inverted U-shaped EKC effect of the company asset size on its carbon emissions.

Similarly, since energy plays a vital role in the performance of the macro-economy, the energy factor will be taken into account in the analogy analysis, which is also in line with our other research topic focus in this paper. To be more closed to the complex environment faced by the company, this paper verifies the effect of oil price fluctuations and company size on carbon emissions at the same time.

\section{Methodology}

\section{The EIO-LCA method}

The EIO-LCA method is an economic model constructed by Carnegie Mellon University. Later, with Matthews and Small (2000) further expanding its use boundary, the EIO-LCA method is gradually widely applied to calculate the carbon footprint of various economic activities. The EIO-LCA method used in this paper adopts the practical experience of Ritchie and Dowlatabadi (2014) and Wei and Shu (2021). Compared with other widely used carbon footprint calculation methods, such as the IPCC method and I-O method, the EIO-LCA method is more comprehensive in the calculation process of carbon footprint. Furthermore, we extend the EIO-LCA approach to evaluate the carbon footprint at the corporate level combining the way of Chapple et al. (2013) and Shen and Huang (2019). The data definitions and data sources used in this section are shown in Table 1, and the steps are as follows:

First, we calculate the carbon footprint of each industry by the EIO-LCA method (considering the actions of the IPCC method in this step $^{1}$ : the carbon emissions from energy

\footnotetext{
1 This paper uses the IPCC method for reference to measure carbon emissions from energy consumption activities and industrial production process, as follows: (1) Obtain the amount of energy consumption of each industry in each year from China "Energy Statistics Yearbook", convert it into standard coal and calculate the carbon emissions caused by each energy consumption; (2) carbon emissions from the industrial production process are slightly different from direct energy consumption, mainly measuring carbon emissions from chemical industry process.
}

activities and carbon emissions from industrial production processes, including cement and ferrous metals).

$B=R(I-A)^{-1} Y$,

where $B$ is the carbon emission matrix of each department; $R$ is the direct emission coefficients of each sector; and $(I-A)^{-1}$ represents the intermediate input-output structure of the economy. $Y$ is the final usage of products and services of each sector.

The carbon emission from fossil fuel combustion $\left(C_{e}\right)$ refers to the carbon emission from the burst of fossil energy directly input in production or service provision, and its calculation formula is as follows:

$C_{e}=\sum_{k=1}^{n} A_{i, k} \times C_{k}$,

where $A_{i, k}$ is the consumption of energy $k$ of industry $i$ and $C_{k}$ is the carbon emission coefficient of energy $k$ (Table 2).

And the specific formula for the carbon emission of the industrial production process of various sectors refers to Wei and Shu (2021) is as follows:

$C_{p}=\sum P_{i, j} \times K_{i, j} \times \frac{12}{44}$,

where $P_{i, j}$ is the output of $j$ industrial products of the $i$ production sector and $K_{i, j}$ is the carbon emission coefficient of the production process of industrial product $j$ of $i$ production sector (see Table 3). The sum of the direct and indirect carbon footprints is the industry's carbon footprint.

Then the second step is to calculate the companies' carbon footprint based on the financial data at the enterprise level and combined with industry data referring to Chapple et al. (2013) and Shen and Huang (2019):

$E_{m}=F_{m} \times \frac{O_{m}}{O_{i, m}}$,

where $E_{m}$ is the carbon footprint of company $m ; F_{m}$ is the total carbon footprint of the industry $i$ that company $m$ belongs to; $O_{m}$ is the cost of the central business; and $O_{i, m}$ is the total cost of the main business of the industry $i$.

Through the above operations, we have obtained the carbon footprint of various industries. This carbon footprint calculation method considers the direct carbon emission of energy consumption and the carbon emission of the industrial production process and the flow of carbon footprint brought by the product or raw material supply chain between industries, showing the carbon footprint its distribution more scientifically. Finally, on this basis, we combined the specific financial situation of the industry and enterprises and obtained the carbon emissions of enterprises from the perspective of the economic activities of enterprises. 
Table 1 Data sources of the measurement of the carbon footprint

The name of the data

Industry energy consumption of physical quantity

The standard coal conversion coefficient

Synthetic ammonia, soda, iron alloy, cement output

Black and non-ferrous metal calendering coke usage

Input-output basic flow chart

Table of direct consumption coefficient of input and output

Industrial industry main business cost

Basic information of bonds (time, maturity, etc.)

Issuer information (financial and non-financial information)

Non-industrial industry main business income and cost

Crystalline silicon, ferrochrome output

Calcium carbide production
The data source

China Energy Statistical Yearbook

China Statistical Yearbook and authors' calculation

China Industry Statistical Yearbook

The Wind and iFind database

World Mineral Production Report

China Calcium Carbide Association

\section{Measurement of crude oil price volatility and empirical model}

At present, two calculation methods are widely used in measuring the fluctuation of crude oil price: One is to use the daily series of international crude oil prices to calculate the standard deviation to express the volatility (Sadorsky 2008; Henriques and Sadorsky 2011). And the other one is to measure it using a method generated from the GARCH model (Hamilton 2003; Yoon and Ratti 2011). In this paper, the measurement of oil price volatility $\left(O V_{t}\right)$ refers to the latest research of Phan et al. (2019) and Maghyereh and Abdoh (2020). In short, the standard deviation of daily returns of oil prices is adopted as the calculation basis of oil price uncertainty. The equation is as follows:

$O V_{t}=\sqrt{\frac{1}{N-1} \sum_{t=1}^{N}\left(r_{t}-E\left(r_{t}\right)\right)^{2}} \times \sqrt{N}$

where $r_{t}$ is the daily WTI oil price return defined as $r_{t}=\ln$ $\left(\underline{p}_{t} p_{t-1}\right), P_{t}$ denotes the WTI crude oil price and $E\left(r_{t}\right)$ is the mean value of $r_{t}$. The $N$ is the number of trading days. At the same time, we also conducted the same treatment and calculation on Brent crude oil price as one of the follow-up robustness tests.
After the calculation of oil price fluctuation, we then model the verification of the EKC curve. We refer to the traditional EKC test method of Saboori et al. (2012), Shen et al. (2018) and Zhang et al. (2019a). We use the company's total assets to represent the development scale of the company and then verify the existence of the EKC inverted U-shaped curve by setting the square term of it. At the same time, due to the large gap between the company's asset scale (ASSET), the company's carbon emissions $(E)$ and other variables, referring to the practice of the above scholars, we take the natural logarithm form of the two variables, obtaining $L N E$ and LNASSET. Starting from the content and purpose of the research, combined with the experience of Wang et al. (2017b) and other scholars' research about China in the theme of EKC, we choose a panel regression model, and the formula is as follows:

$$
\begin{aligned}
L_{N E E_{i, t}=} & \alpha_{0}+\alpha_{1} O V_{t}+\alpha_{2} L_{N A S S E T} T_{i, t}+\alpha_{3} \operatorname{LNASSET}_{i, t}^{2} \\
& +\alpha_{i} Z_{i, t}+\sigma_{f}+\mu_{i, t},
\end{aligned}
$$

where the $L N E_{i, t}$ and $O V_{t}$ are the company's carbon emissions and volatility of the WTI crude oil price; the $L N A S S E T_{i, t}$ is the natural logarithm of the size of a company's total assets; $Z_{i, t}$ is the set of control variables at the corporate level; the $\sigma_{f}$ represents the fixed effects; and the $\mu_{i, t}$ is the error term.

\begin{tabular}{|c|c|c|c|c|c|c|c|c|}
\hline Energy varieties & Coal & Coke & Crude oil & Gasoline & Kerosene & Diesel & Fuel oil & Natural gas \\
\hline Standard coal conversion coefficient & 0.7143 & 0.9714 & 1.4286 & 1.4714 & 1.4714 & 1.4571 & 1.4286 & 1.3300 \\
\hline Carbon emission factor & 0.7559 & 0.8550 & 0.5857 & 0.5538 & 0.5714 & 0.5921 & 0.6185 & 0.4483 \\
\hline
\end{tabular}

Table 2 Standard coal conversion coefficient and carbon emission coefficient of different energy types

Note: The conversion unit of the first seven energy types in the standard coal conversion coefficient is "kg ce/kg" of material quantity. Natural gas is "kg $\mathrm{ce} / \mathrm{m}^{3}$ "; the unit of measurement of carbon emission coefficient is " $\mathrm{kg} \mathrm{C} / \mathrm{kg}$ ce" 
Table 3 Carbon emission coefficient of the industrial production process

\begin{tabular}{|c|c|c|}
\hline The production department & Industrial process & $\begin{array}{l}\text { Carbon emission } \\
\text { coefficient }\left(\mathrm{T} \mathrm{CO}_{2} / \mathrm{t}\right)\end{array}$ \\
\hline \multirow[t]{3}{*}{ Chemical raw materials and chemical products manufacturing } & Synthetic ammonia & 1.500 \\
\hline & Calcium carbide & 1.100 \\
\hline & Soda ash & 0.415 \\
\hline Non-metallic mineral products & Cement & 0.395 \\
\hline \multirow[t]{4}{*}{ The ferrous metal smelting and rolling processing industry } & Ferrochrome & 1.300 \\
\hline & Crystalline silicon & 4.300 \\
\hline & Other iron & 4.000 \\
\hline & Coke (as a reducing agent) & 3.100 \\
\hline The non-ferrous metal smelting and rolling processing industry & Coke (as a reducing agent) & 3.100 \\
\hline
\end{tabular}

Control variables include the fundamental nature of the company and the financial performance of the company. The selection and calculation of control variables and data sources are shown in Table 4. Through the processes above, the basic regression model and the required variables are ready.

\section{Data source and empirical results}

\section{Data}

In the calculation process of the EIO-LCA method, to ensure the consistency of the samples and through reasonable screening and classification, companies with missing data, short operating years and poor operating conditions are eliminated. After filtration and due to data limitations, the final selection covers 1,089 companies. The whole sample includes 39 industries (shown in Table 5) and 30 provinces and regions, basically considering China's entire sector and area. We carried out an accurate calculation of carbon footprint for each industry by using the specific energy consumption of every sector in the Energy Statistics Yearbook reasonably. Based on the input-output tables of various departments in China, we calculated the direct consumption coefficient and indirect consumption of each industry.

Then we choose WTI crude oil price as the representative index (Maghyereh and Abdoh 2020) and calculate the annual oil price volatility through the daily data return series, which is the main explanatory variable in this paper. We also used Brent crude oil price and the Oil Volatility Index (OVX) launched by the Chicago Board Options Exchange (CBOE) in the robustness test. At the same time, to reduce the interference of economic development and economic policy uncertainty (EPU), the GDP of China and the global EPU index will be controlled.
The data used in the carbon emission calculation process and GDP data are basically from various statistical yearbooks published by the National Bureau of Statistics of China. The company's financial data and basic information are derived from Wind and iFind databases, the most widely used and comprehensive databases in China. We get the original sequences of WTI crude oil price and Brent crude oil price from the Federal Reserve Bank of St. Louis and Intercontinental Exchange $^{2}$. See Table 1 and Table 4 for the introduction of specific variables and more details, and the time interval of this study is 2009-2018.

To smooth the data and keep the data size consistent, we made Winsor tail reduction for the continuous variables according to the data characteristics. The descriptive statistics of the final sample are shown in Table 6. From the description statistics, we can see 10,856 observation points in 10 years after treatment. More companies in our sample are located in the eastern region, and more state-owned companies and nonlisted companies are there. It can be seen that the maximum and minimum values of the company's carbon emission data and assets are still somewhat different after logarithmic processing, but their data distributions are relatively balanced, and the standard deviations are not exaggerated. The Brent oil price volatility index has the smallest mean value $(0.13)$ and the smallest standard deviation $(0.047)$ of the three oil price volatility indices.

\section{Regression results}

From the main regression results (Table 7), we can see that the first column is the primary regression result under fixed effect. The regression coefficient of oil price volatility $\left(O V_{t}\right)$ to carbon emissions $\left(L N E_{t}\right)$ is -0.0469 , which is significant at $1 \%$

\footnotetext{
${ }^{2}$ The Chicago Board Options Exchange released the Oil Volatility Index (OVX), and the uncertainty of global economic policy came from the website http://www.policyuncertainty.com/index.html.
} 
Table 4 Definition of variables and data sources in the empirical process

\begin{tabular}{lll}
\hline Variable & Definition & Source \\
\hline$E_{t}$ & Corporate carbon emissions & Calculation by authors \\
$O V_{t}$ & WTI crude oil price uncertainty; an annual average & Calculation by authors \\
of the standard deviation of daily returns of oil prices & The Oil Volatility Index launched by the Chicago Board Options Exchange (CBOE) & The Chicago Board Options Exchange \\
$B R E N T_{t}$ & Brent crude oil price uncertainty & Calculation by authors \\
$G D P_{t}$ & Gross domestic product of China & China national bureau of statistics \\
$E P U_{t}$ & Global Economic Policy Uncertainty & http://policyuncertainty.com/index. \\
& & html \\
$A S S E T_{t}$ & Total assets & Wind and iFind databases \\
$L E V_{t}$ & Firm leverage ratio; calculated as total debt scaled by total assets & Wind and iFind databases \\
$C F_{t}$ & Net cash flows from operating activities & Wind and iFind databases \\
$P R O F I T_{t}$ & Net operating profit & Wind and iFind databases \\
$S A_{t}$ & The financing constraints; SA index & Calculation by authors \\
$L N A G E_{t}$ & Length of establishment & Calculation by authors \\
$C O M$ & Dummy variable; 1 for listed companies and 0 for unlisted companies & Wind and iFind databases \\
$S O E$ & Dummy variable; 1 for state-owned enterprises and 0 for non-state-owned enterprises & Wind and iFind databases \\
$A R$ & Dummy variable; 1 for the western region, 2 for the central region, and 3 for the eastern region & Wind and iFind databases \\
$I N D U$ & Industry of the company & Classification by authors \\
\hline
\end{tabular}

significance level. It indicates that one more unit of oil price uncertainty decreases the company's carbon emission by 0.0469 units. That is, the more uncertain the oil price is, the less carbon the companies will emit. The second column shows the regression result after adding the square term of assets. The regression coefficient of oil price volatility on corporate carbon emissions has changed to -0.0141 , but the significance level has not changed. Statistically speaking, this result shows that hypothesis $1(H 1)$ is valid. The fluctuation of oil prices will indeed affect firms' carbon footprint, and the increase of oil price uncertainty will inhibit carbon emissions.

Then we focus on the results of the asset term (LNASSET $\left.T_{t}\right)$ and its square term. In the results in the first column, the regression coefficient of corporate assets to corporate carbon emissions is 0.2975 , which becomes 0.2700 after adding the square term, and the coefficient of the square asset term is -0.0443 . From a mathematical point of view, the two influence coefficients with opposite signs mean the existence of an "inverted U"-shaped curve. All of the results above are statistically significant at $1 \%$ significance level. These results indicate that the expansion of corporate assets will increase corporate carbon emissions, but subsequent development will inhibit carbon emissions when the growth reaches a particular level. Mathematically, the inverted U-shaped curve of corporate assets versus corporate carbon emissions holds. In other words, our hypothesis 2 (H2) has also been verified, and the EKC effect on carbon emissions exists at the corporate level.

After testing the assumptions, we conducted sub-sample studies on the impact of corporate heterogeneity, and the results are shown in Tables $8,9,10$ and 11. From these results, corporate heterogeneity has primarily contributed to the differences in response to volatility in oil prices. We can see that all companies' ownership, whether listed on the stock exchange or not, and the degree of environmental sensitivity significantly influence the results.

As ownership has been proved to impact the environmental performance of corporates substantially in many documents (Eaton and Kostka 2017; Cheng and Liu 2018), we first experimented on the ownership, and a very unexpected result has emerged. For state-owned enterprises (SOES), the impact coefficient of oil price fluctuation on their carbon emissions is -0.0231 . For non-state-owned enterprises (non-SOEs), the impact coefficient is 0.0074 , and the two coefficients above are significant at $1 \%$ and $5 \%$ significance levels, respectively. The results show that when the uncertainty of oil price increases, the carbon emissions of state-owned enterprises will decrease, while those of non-state-owned enterprises will increase. Moreover, the impact of oil price fluctuations on stateowned enterprises is relatively more remarkable and more significant.

The possible reasons for this result are as follows: firstly, as the state-owned enterprises represented by China National Petroleum Corporation Limited in the sample have mastered the lifeline of China's oil import and export, and their main business is also oil-related economic activities (Yorbana 2016; Li et al. 2021). Then, for these state-owned enterprises, the influence of the fluctuations in crude oil prices will be more significant and more apparent. Secondly, there is another 
Table 5 Classification of industry sectors

\begin{tabular}{|c|c|}
\hline Code & Sector \\
\hline 01 & Agriculture, forestry, animal husbandry and fishery \\
\hline 02 & Coal mining and washing industry \\
\hline 03 & Oil and gas exploration \\
\hline 04 & Ferrous metal mining and processing industry \\
\hline 05 & Non-ferrous metal mining and dressing industry \\
\hline 06 & Non-metallic ore mining and other mining industries \\
\hline 07 & Agricultural and sideline food processing industry \\
\hline 08 & Food manufacturing \\
\hline 09 & Liquor, beverage and refined tea manufacturing \\
\hline 10 & Textile industry \\
\hline 11 & The textile and apparel industry \\
\hline 12 & Leather, fur, feather and their products and footwear \\
\hline 13 & Wood processing and wood, bamboo, rattan, palm, grass products \\
\hline 14 & Furniture manufacturing \\
\hline 15 & Papermaking and paper products \\
\hline 16 & Culture and education, industrial beauty, sports and entertainment goods manufacturing \\
\hline 17 & Chemical raw materials and chemical products manufacturing \\
\hline 18 & Pharmaceutical manufacturing \\
\hline 19 & Chemical fibre manufacturing \\
\hline 20 & Rubber and plastic products \\
\hline 21 & Non-metallic mineral products \\
\hline 22 & The ferrous metal smelting and rolling processing industry \\
\hline 23 & The non-ferrous metal smelting and rolling processing industry \\
\hline 24 & Metal products \\
\hline 25 & General equipment manufacturing \\
\hline 26 & Special equipment manufacturing \\
\hline 27 & Transportation equipment manufacturing industry \\
\hline 28 & Electrical machinery and equipment manufacturing \\
\hline 29 & Manufacturing of computers, communications and other electronic equipment \\
\hline 30 & Instrumentation manufacturing \\
\hline 31 & Other manufacturing industries \\
\hline 32 & Comprehensive utilization of waste resources \\
\hline 33 & Production and supply of electricity and heat \\
\hline 34 & Gas production and supply industry \\
\hline 35 & The production and supply of water \\
\hline 36 & The construction industry \\
\hline 37 & Wholesale, retail and accommodation and catering industries \\
\hline 38 & Transportation, warehousing and postal services \\
\hline 39 & Other industries \\
\hline
\end{tabular}

Note: (i) "other industries" includes a dozen industries, including education and scientific research. (ii) In order to accurately measure the carbon emissions caused by the energy consumption of various industries, the industry classification in this paper is mainly based on China's "Energy Statistics Yearbook" of each year, making the industry groupings matched with the official physical data of energy consumption as much as possible possibility that private enterprises are more sensitive to the market and react faster to various shocks than state-owned enterprises. The state-owned enterprises are relatively more inclined to the conservative corporate strategy (Peng et al.
2016; Song 2018), so they will choose a safer production and operation mode when the oil price fluctuates.

This opposite result also appears between the listed companies (LISTS) and non-listed companies (un-LISTs). Listed 
Table 6 Descriptive statistics of the variables during 2009-2018.

\begin{tabular}{lllllll}
\hline VarName & Obs & Mean & SD & Min & Median & Max \\
\hline LNE $_{t}$ & 10856 & 8.75 & 3.807 & 1.604597 & 8.765905 & 17.21045 \\
$O V_{t}$ & 10856 & 4.03 & 2.250 & 1.24939 & 2.9011 & 8.39728 \\
LNASSE $_{t}$ & 10856 & 14.43 & 1.487 & 10.37883 & 14.48586 & 17.89209 \\
LEV $_{t}$ & 10856 & 0.56 & 0.171 & .1125605 & .5765823 & .8882838 \\
SA $_{t}$ & 10856 & -2.20 & 0.738 & -3.578956 & -2.241085 & .1127756 \\
LNGDP $_{t}$ & 10856 & 2.06 & 0.162 & 1.882053 & 1.987808 & 2.364258 \\
LNEPU $_{t}$ & 10856 & 4.67 & 0.718 & 3.790635 & 4.570713 & 6.239961 \\
COM & 10856 & 0.43 & 0.495 & 0 & 0 & 1 \\
SOE & 10856 & 0.71 & 0.454 & 0 & 1 & 1 \\
AR & 10856 & 2.50 & 0.734 & 1 & 3 & 3 \\
LNAGE $_{t}$ & 10856 & 2.82 & 0.352 & 1.791759 & 2.833213 & 4.219508 \\
CF $_{t}$ & 10856 & 14.29 & 49.893 & -81.55338 & 2.673613 & 333.2007 \\
PROFIT $_{t}$ & 10856 & 10.88 & 26.241 & -18.42376 & 2.520285 & 171.0611 \\
OVX $_{t}$ & 10856 & 34.78 & 9.141 & 22.33917 & 31.28333 & 51.425 \\
BRENT $_{t}$ & 10856 & 0.13 & 0.047 & .07654 & .1221921 & .2228072 \\
\hline
\end{tabular}

Note: (i) All monetary variables, "millions of RMB"; carbon emissions, "tons"; time, "years"

companies in this paper refer to companies listed on stock exchanges for equity financing, including the Shanghai Stock Exchange and Shenzhen Stock Exchange. From Table 8 , the influence coefficient of oil price fluctuation on listed companies' carbon emissions is 0.0060 , and the impact coefficient on unlisted companies is -0.0302 . We can see that

Table 7 Main empirical results

\begin{tabular}{|c|c|c|}
\hline Variables & (1) & (2) \\
\hline & $L N E_{t}$ & $L N E_{t}$ \\
\hline$O V_{t}$ & $-0.0469 * * *(-7.89)$ & $-0.0141 * * *(-7.86)$ \\
\hline${ }_{L N A S S E T}$ & $0.2975 * * *(6.09)$ & $0.2700 * * *(5.64)$ \\
\hline $\operatorname{LNASSET}_{t} * L N A S S E T_{t}$ & & $-0.0443 * * *(-3.90)$ \\
\hline$L E V_{t}$ & $-0.1737 * * *(-2.78)$ & $-0.0352(-0.35)$ \\
\hline$S A_{t}$ & $1.1726 * * *(9.78)$ & $2.0955^{* * *}(8.38)$ \\
\hline$L N G D P_{t}$ & $2.1190 * * *(12.41)$ & $0.7264 * * *(4.97)$ \\
\hline$L N E P U_{t}$ & $-0.1130 * * *(-2.95)$ & $0.1108 * * *(7.28)$ \\
\hline$C F_{t}$ & $0.0004 *(1.80)$ & $0.0014 * * *(4.10)$ \\
\hline $\mathrm{PROFIT}_{t}$ & $-0.0002(-0.46)$ & $-0.0011(-1.41)$ \\
\hline Constant & $7.0203 * * *(9.17)$ & $11.4586^{* * *}(10.09)$ \\
\hline Observations & 10,856 & 10,856 \\
\hline$R$-squared & 0.1652 & 0.1422 \\
\hline$F$ & 137.8 & 179.8 \\
\hline
\end{tabular}

Note: (i) Regression models have controlled individual and year effects. (ii) The first column is the basic regression result of the sample, and the second column is the regression result with the square term of the company's assets added. (iii) The “*”, “**” and “***” indicates $1 \%$, $5 \%$ and $10 \%$, significance level
Table 8 Regressions results for ownership

\begin{tabular}{|c|c|c|}
\hline Variables & $\begin{array}{l}\text { SOEs } \\
L N E_{t}\end{array}$ & $\begin{array}{l}\text { Non-SOEs } \\
L N E_{t}\end{array}$ \\
\hline$O V_{t}$ & $-0.0231 * * *(-10.72)$ & $0.0074 * *(2.29)$ \\
\hline LNASSET $_{t}$ & $0.1289(1.46)$ & $0.4943 * * *(7.01)$ \\
\hline LNASSET $_{t} *$ LNASSET $_{t}$ & $-0.0391 * * *(-2.65)$ & $-0.0658 * * *(-3.18)$ \\
\hline$L E V_{t}$ & $-0.0840(-0.63)$ & $0.1166(0.75)$ \\
\hline$S A_{t}$ & $2.2492 * * *(7.45)$ & $1.9560 * * *(4.42)$ \\
\hline$L N G D P_{t}$ & $0.5783 * * *(3.25)$ & $0.9622 * * *(3.80)$ \\
\hline$L N E P U_{t}$ & $0.1286 * * *(7.07)$ & $0.0793 * * *(2.86)$ \\
\hline$C F_{t}$ & $0.0015 * * *(3.97)$ & $0.0013(1.40)$ \\
\hline PROFIT $_{t}$ & $-0.0025 * * *(-2.84)$ & $0.0043 * *(2.37)$ \\
\hline Constant & $12.3473 * * *(8.92)$ & $10.8648 * * *(5.42)$ \\
\hline Observations & 7,701 & 3,155 \\
\hline$R$-squared & 0.1258 & 0.2055 \\
\hline$F$ & 110.7 & 81.33 \\
\hline
\end{tabular}

Note: (i) Regression models have controlled individual and year effects. (ii) The SOEs in the sample include central and local state-owned enterprises, and non-SOEs include private enterprises, foreign-funded enterprises and Sino-foreign joint ventures. (iii) The “*”, “**” and “***" indicates $1 \%, 5 \%$ and $10 \%$, significance level.

the oil price fluctuation has a significantly positive effect on the listed companies at 5\% significance level. And it makes a negative impact on the non-listed company at $1 \%$ significance level. The impact on unlisted companies is more pronounced. As we all know, listed companies generally have greater

Table 9 Regressions results for the listed and unlisted corporate

\begin{tabular}{|c|c|c|}
\hline Variables & $\begin{array}{l}\text { LISTs } \\
L N E_{t}\end{array}$ & $\begin{array}{l}\text { un-LISTs } \\
L N E_{t}\end{array}$ \\
\hline$O V_{t}$ & $0.0060 * *(2.26)$ & $-0.0302 * * *(-12.43)$ \\
\hline$L_{N A S S E T}$ & $0.3934 * * *(6.40)$ & $-0.0767(-0.63)$ \\
\hline LNASSET $_{t} * L N A S S E T_{t}$ & $-0.0392 * *(-2.41)$ & $-0.0349 *(-1.89)$ \\
\hline$L E V_{t}$ & $0.1787(1.37)$ & $-0.2294(-1.43)$ \\
\hline$S A_{t}$ & $1.5930 * * *(4.66)$ & $2.5814 * * *(7.07)$ \\
\hline$L N G D P_{t}$ & $0.9409 * * *(4.56)$ & $0.4235 * *(2.07)$ \\
\hline$L N E P U_{t}$ & $0.1467 * * *(6.57)$ & $0.0865 * * *(4.14)$ \\
\hline$C F_{t}$ & $0.0011 *(1.92)$ & $0.0015 * * *(3.40)$ \\
\hline PROFIT $_{t}$ & $0.0021 *(1.66)$ & $-0.0032 * * *(-3.18)$ \\
\hline Constant & $9.9430 * * *(6.25)$ & $14.0260 * * *(8.61)$ \\
\hline Observations & 4,697 & 6,159 \\
\hline$R$-squared & 0.1907 & 0.1228 \\
\hline$F$ & 110.5 & 86.06 \\
\hline
\end{tabular}

Note: (i) Regression models have controlled individual and year effects. (ii) Listed companies refer to companies listed on Shenzhen Stock Exchange or Shanghai Stock Exchange and also include companies listed in Hong Kong and overseas. (iii) The "**" " “**” and "****" indicates $1 \%$, $5 \%$ and $10 \%$, significance level. 
Table 10 Regressions results for environmental sensitivity

\begin{tabular}{|c|c|c|}
\hline Variables & Environmentally sensitive $L N E_{t}$ & Environmental insensitive $L N E_{t}$ \\
\hline$O V_{t}$ & $-0.0005(-0.24)$ & $-0.0179 * * *(-8.09)$ \\
\hline LNASSET $_{t}$ & $0.2829 * * *(4.22)$ & $0.2764 * * *(4.68)$ \\
\hline $\operatorname{LNASSET}_{t} * L N A S S E T_{t}$ & $-0.0026(-0.18)$ & $-0.0562 * * *(-3.95)$ \\
\hline$L E V_{t}$ & $0.2593 *(1.84)$ & $-0.0400(-0.32)$ \\
\hline$S A_{t}$ & $0.8820 * * *(2.75)$ & $2.4629 * * *(7.93)$ \\
\hline$L N G D P_{t}$ & $0.1964(1.08)$ & $0.9531 * * *(5.22)$ \\
\hline$L N E P U_{t}$ & $0.0909 * * *(4.66)$ & $0.1144 * * *(6.07)$ \\
\hline$C F_{t}$ & $0.0005(1.08)$ & $0.0014 * * *(3.25)$ \\
\hline PROFIT $_{t}$ & $0.0004(0.59)$ & $-0.0013(-1.07)$ \\
\hline Constant & $12.1098 * * *(8.28)$ & $11.0135 * * *(7.82)$ \\
\hline Observations & 2,528 & 8,328 \\
\hline$R$-squared & 0.3063 & 0.1331 \\
\hline$F$ & 111.2 & 127.7 \\
\hline
\end{tabular}

Note: (i) Regression models have controlled individual and year effects. (ii) The environmentally sensitive companies refer to the policy document issued by the Ministry of Environmental Protection of the PRC in 2008, which contains 16 industries, mainly heavy polluting industries. (iii) The “*”, “**” and “***” indicates $1 \%, 5 \%$ and $10 \%$, significance level. capital strength and stronger operation ability (Darko et al. 2016). Therefore, in the face of the impact of oil prices, they may not restrain their daily business activities, so their carbon emissions will not be greatly affected.

Then we studied the role of the environmental sensitivity of corporates. Our division of environmentally sensitive industries refers to the policy paper "the Catalogue of Industries for Environmental Protection Verification of Listed Companies" published in 2008 by the ministry of environmental protection of the PRC, which includes 16 sectors and the rest are environmentally insensitive industries. As can be seen from Table 10, the response of environmentally sensitive enterprises to oil price fluctuations is not as apparent as that of non-environmentally sensitive enterprises, even has no significant statistical correlation. To a certain extent, oil price fluctuations cannot affect the carbon-related activities of these environmentally sensitive enterprises. This result is very different from the previous research results that many scholars believe that environmentally sensitive companies will pay more attention to carbon emission information and take more
Table 11 Regressions results for geographical distribution

\begin{tabular}{|c|c|c|c|}
\hline Variables & $\begin{array}{l}\text { Western region } \\
L N E_{t}\end{array}$ & $\begin{array}{l}\text { Central region } \\
L N E_{t}\end{array}$ & $\begin{array}{l}\text { Eastern region } \\
L N E_{t}\end{array}$ \\
\hline$O V_{t}$ & $-0.0203 * * *(-4.36)$ & $-0.0245 * * *(-6.36)$ & $-0.0090 * * *(-4.06)$ \\
\hline$L_{N A S S E T}$ & $0.1486(1.08)$ & $0.5276 * * *(5.12)$ & $0.2466^{* * *}(4.18)$ \\
\hline$L_{N A S S E T} * L N A S S E T_{t}$ & $-0.1079 * * *(-3.34)$ & $-0.0232(-0.89)$ & $-0.0425 * * *(-3.09)$ \\
\hline$L E V_{t}$ & $0.1423(0.58)$ & $-0.3293(-1.53)$ & $-0.0194(-0.15)$ \\
\hline$S A_{t}$ & $4.2552 * * *(5.90)$ & $1.1828 * *(2.11)$ & $1.8130 * * *(5.99)$ \\
\hline$L N G D P_{t}$ & $-0.0979(-0.24)$ & $0.8083 * *(2.48)$ & $0.8086^{* * *}(4.57)$ \\
\hline$L N E P U_{t}$ & $0.1018 * *(2.42)$ & $0.0013(0.04)$ & $0.1528 * * *(8.23)$ \\
\hline$C F_{t}$ & $0.0048 * * *(3.92)$ & $0.0006(0.60)$ & $0.0011 * * *(2.92)$ \\
\hline PROFIT $_{t}$ & $-0.0057 * *(-2.42)$ & $0.0010(0.42)$ & $0.0001(0.09)$ \\
\hline Constant & $19.6120 * * *(6.01)$ & $7.7806 * * *(3.13)$ & $10.7311 * * *(7.76)$ \\
\hline Observations & 1,570 & 2,303 & 6,983 \\
\hline$R$-squared & 0.2810 & 0.2035 & 0.1023 \\
\hline$F$ & 60.98 & 58.57 & 79.41 \\
\hline
\end{tabular}

Note: (i) Regression models have controlled individual and year effects. (ii) The division of the eastern, central and western regions refers to the rules in China's economic census, which includes both geographical location factors and certain economic factors. (iii) The '*', '**', and '***' indicates $1 \%, 5 \%$, and $10 \%$, significance level. 
active actions to improve their environmental performance (Kuo and Yu 2017; Dias et al. 2019). As in our industry segment, environmentally sensitive companies are mainly composed of heavily polluting industries, such as electricity production, chemical industry and energy mining. These industries rely on resources such as crude oil to maintain their daily operations. Even if the oil price changes, these industries will have to continue to consume crude oil, resulting in the company's carbon footprint not reacting violently to such fluctuations.

Furthermore, the geographical distribution of the companies does not seem to have a noticeable difference in the influence of oil price fluctuations on the companies' carbon emissions. As shown in Table 10, the changes in oil price will negatively affect the company's carbon emissions, whether the eastern, central or western regions and the influence coefficients are $-0.0090,-0.0245$ and -0.0203 , respectively. All of them significant at the $1 \%$ level, but in terms of numerical value, the impact of crude oil price volatility on the carbon footprint of firms located in the east part is relatively more minor.

This result may be related to China's environmental efficiency, which is mainly driven by air pollutant emissions, carbon emissions and fossil energy utilization. From a spatial point of view, from northern China to southern China, the environmental inefficiency shows a downward trend. Geographically, it is also consistent with the regions divided by our sample. Companies in the eastern region are basically located in the south and southeast, with higher environmental efficiency and less impact from fossil energy (Miao et al. 2019). It may also be due to the fact that the tertiary industry dominates the eastern part of China, and the high-tech industry and service industry are smashing. Compared with the central and western regions where industrial enterprises are relatively concentrated, the demand for crude oil is relatively small, so the sensitivity to fluctuations in oil prices is relatively slight.

The analysis of different results caused by the heterogeneity of the company gives more details on the impact of oil price fluctuations on the company's carbon footprint. Our hypothesis $1(\mathrm{Hl})$ is tenable for the companies in the sample as a whole, but this is not always the case in different sub-samples, providing more entry points for subsequent research. For different types of companies, the influence is distinct. The mechanism behind this may also be a research issue worthy of attention.

In addition, whether in the main regression results or the test results of each sub-sample, the performance of the impact of corporate assets on the carbon footprint is almost the same. The contribution of asset size to corporate carbon footprint and the inhibition of square item of asset size to corporate carbon footprint is very significant ( $1 \%$ level) in most cases. However, in the sample of state-owned enterprises and non- listed companies, there are also some tiny episodes. Although the impact coefficient of state-owned enterprise assets is 0.1289 , there is no significant impact. For non-listed companies, the impact coefficient of assets is -0.0767 , the only negative value among all results, but it is not substantial. However, overall, the negative impact of the square item of assets in all tests is stable and robust.

This phenomenon shows that hypothesis 2 (H2), the EKC inverted U-shaped effect of corporate assets on carbon emissions, is established and convincing. At the corporate level in China, we have obtained similar EKC effects at the macrolevel (He and Wang 2012; Li et al. 2016; Jiang et al. 2021a). This result allows us to know the interesting story about the company's development level and the company's environmental performance, indicating that continuous development will improve the company's carbon emissions when the company's scale develops to a certain level.

\section{Robust tests}

In this part, the robustness is tested by using two alternative indicators of oil price volatility. The first approach is to directly use the OVX index, launched by the Chicago Board Options Exchange in the USA, referring to He et al. (2020). The OVX index contains historical information about oil and investors' expectations. In many cases, it is considered as a more direct and better measure of oil price uncertainty than historical price series (Maghyereh et al. 2016; Xiao et al. 2018). This part uses it as an alternative to oil price volatility that includes more perspectives, and we average the daily data to obtain annual fluctuations.

Another way is to replace the WTI crude oil price with the Brent crude oil price in the calculation process of oil price volatility. Brent crude oil is also the crude oil data commonly used in the literature of many economic fields (Abdollahi and Ebrahimi 2020), and we take it as another international representative crude oil to robust our research.

In the robustness test results (Table 12), the impact coefficient of $O V X_{t}$ is -0.0073 , and the impact coefficient of Brent crude oil price volatility $\left(B R E N T_{t}\right)$ is -0.7711 . In connection with the impact of WTI crude oil price volatility $\left(O V_{t}\right)$ on the carbon footprint above, the three crude oil price uncertainties significantly negatively impact corporate carbon emissions, indicating that the influence of international crude oil price volatility on Chinese companies is undeniable. Numerically, the fluctuations in Brent crude oil price will have a more severe impact on the company's carbon emissions. In addition, the impact direction and significance of assets are consistent with the previous empirical results, proving that the conclusions of our research can stand the test. The main results of the robustness test are all valid at a $1 \%$ significance level, which proves the validity of our two hypotheses again. 
Table 12 Robustness test: alternative variables of crude oil price volatility

\begin{tabular}{|c|c|c|}
\hline Variables & $\begin{array}{l}(1) \\
L N E_{t}\end{array}$ & $\begin{array}{l}(2) \\
L N E_{t}\end{array}$ \\
\hline$O V X_{t}$ & $-0.0073 * * *(-7.58)$ & \\
\hline$B R E N T_{t}$ & & $-0.7711 * * *(-4.23)$ \\
\hline$L N A S S E T_{t}$ & $1.1573 * * *(5.11)$ & $0.2849 * * *(5.93)$ \\
\hline$L_{N A S S E T} * L N A S S E T_{t}$ & $-0.0481 * * *(-4.21)$ & $-0.0423 * * *(-3.70)$ \\
\hline$L E V_{t}$ & $-0.0447(-0.44)$ & $-0.0588(-0.58)$ \\
\hline$S A_{t}$ & $2.1763 * * *(8.66)$ & $2.0382 * * *(8.11)$ \\
\hline$L N G D P_{t}$ & $0.7557 * * *(5.19)$ & $0.7852 * * *(5.35)$ \\
\hline$L N E P U_{t}$ & $0.1198 * * *(7.88)$ & $0.1230 * * *(8.06)$ \\
\hline$C F_{t}$ & $0.0014 * * *(4.06)$ & $0.0014 * * *(3.85)$ \\
\hline PROFIT $_{t}$ & $-0.0011(-1.39)$ & $-0.0010(-1.26)$ \\
\hline Constant & $5.1110 * * *(4.95)$ & $10.9268 * * *(9.58)$ \\
\hline Observations & 10,856 & 10,856 \\
\hline R-squared & 0.1418 & 0.1384 \\
\hline $\mathrm{F}$ & 179.2 & 174.1 \\
\hline
\end{tabular}

Note: (i) Regression models have controlled individual and year effects. (ii) The robustness test uses two alternative indicators of crude oil price volatility. The first column result from using the OVX indicator released by the Chicago Board Options Exchange, and the second column is the result of the volatility of oil prices that we calculated using Brent crude oil prices. (iii) The "**, “**” and "***" indicates $1 \%, 5 \%$ and $10 \%$, significance level

\section{Conclusions}

The prices of high-pollution energy sources such as crude oil will face more uncertainties since these energies have reached a critical period of business or technological transformation with the low-carbon trend of the global economy, and unexpected shocks such as COVID-19 will also have a significant effect on their prices (Ajami 2020). However, the main energy source of the enterprise is still the traditional energies, while the enterprise itself is also facing multi-party supervision pressure on environmental performance (van Tulder 2018). In the past, the "sustainable development" of the company primarily focused on financial performance, such as the company's capital operation ability. Still, with the widespread concern of corporate social responsibility, "sustainable development" tends to include miscellaneous environmental performance such as carbon emissions and ecological penalties (Abbas and Sağsan 2019; Ikram et al. 2019; Scherer and Voegtlin 2020). Moreover, China's "carbon neutral" goal has further increased the company's challenge and urgency in carbon performance.

This paper investigates the dynamic correlation between corporate carbon emissions and fluctuations in international crude oil prices, as well as the corporate asset size, to grasp the actual connection among these factors accurately. We discovered that the uncertainty of crude oil price could significantly reduce the company's carbon emissions; there is a similar EKC inverted U-shaped curve between the development scale of the company and its carbon emissions.

On the impact of crude oil fluctuations, we found many interesting phenomena through the investigation of corporate heterogeneity. Among several heterogeneity factors, the geographical element of the company's location only plays a negligible impact. In contrast, the company's ownership and whether the company is listed or not will cause the opposite reaction of the company's carbon emissions in the face of the fluctuation of crude oil price. The state-owned enterprises and the unlisted companies will be significantly affected. In addition, companies that are less sensitive to the environment will be involved greater and have more carbon emissions reductions when oil prices fluctuate. Although our hypothesis 1 is not held in some sub-samples, this is another value of the research, and the driving mechanism behind this phenomenon is also a direction that we can dig deep in the future.

The confirmation of the inverted U-shaped curve of the EKC at the corporate level enables us to understand some changes that will be led by the development of the enterprise better. We know that enterprise development will not lead to environmental degradation indefinitely, and there does exist a critical turning point. This finding provides a new reference for corporates to manage their stratagems and the capital structure. For regulators, the control of oil prices has always been a crucial part of economic activities. Our analysis of the relationship between international crude oil price fluctuations and corporate carbon emissions provides policymakers with a new perspective to coordinate the oil prices and low-carbon economic development and helps to promote the improvement of relevant policies.

The shortcoming of this paper is that there might be some discrepancies between the result of the assessment of corporate carbon emissions and the actual level of carbon emissions. However, the company's carbon emission data are seriously missing. To alleviate this problem, we divide the industry as detail as possible into numerous sectors and consider both the direct and indirect carbon emission processes, through which the carbon footprint in each sector can be measured as accurately as possible. Our measurement of corporate carbon emissions could help inspire other researchers to study this important topic in the future.

Author contribution Ping Wei: conceptualization, supervision and writing-reviewing

Yiying Li: data collection, data analysis and writing — original draft preparation

Xiaohang Ren: data analysis, software, methodology and writingediting

Kun Duan: writing — editing 
Funding This research was supported by the General Project of Natural Science Fund of Hunan Province (2019JJ40389) and the Social Sciences Research Grant by Hunan Province (18YBA432).

Data availability Most of the basic data are publicly available, mainly from the National Bureau of Statistics of China, the official website, http://www.stats.gov.cn/, and the Wind and IFind financial databases. Other data are calculated by authors, and the calculation method is shown in the text of this paper.

\section{Declarations}

Ethics approval and consent to participate Not applicable.

Consent for publication Not applicable.

Competing interests The authors declare no competing interests.

\section{References}

Abbas J, Sağsan M (2019) Impact of knowledge management practices on green innovation and corporate sustainable development: a structural analysis. Journal of Cleaner Production 229:611-620

Abdollahi H, Ebrahimi SB (2020) A new hybrid model for forecasting Brent crude oil price. Energy 200:117520

Abhyankar A, Xu B, Wang J (2013) Oil price shocks and the stock market: evidence from Japan. Energy J 34:199-222

Adebayo TS (2021) Testing the EKC hypothesis in Indonesia: empirical evidence from the ARDL-based bounds and wavelet coherence approaches. Applied Economics Journal 28:78-100

Ahmed K, Long W (2013) An empirical analysis of CO2 emission in Pakistan using EKC hypothesis. J Int Trade Law Policy 12:188-200

Ajami, R (2020) Globalization, the challenge of COVID-19 and oil price uncertainty. J Asia-Pac Bus 21:1-3

Allevi E, Basso A, Bonenti F, Oggioni G, Riccardi R (2019) Measuring the environmental performance of green SRI funds: a DEA approach. Energy Economics 79:32-44

Alsalman Z (2016) Oil price uncertainty and the US stock market analysis based on a GARCH-in-mean VAR model. Energy Economics 59: 251-260

Alwi SRW, Klemeš JJ, Varbanov PS (2016) Cleaner energy planning, management and technologies: perspectives of supply-demand side and end-of-pipe management. Journal of Cleaner Production 136: $1-13$

Aslan A, Destek MA, Okumus I (2018) Bootstrap rolling window estimation approach to analysis of the Environment Kuznets Curve hypothesis: evidence from the USA. Environmental Science and Pollution Research 25:2402-2408

Bildirici ME, Badur MM (2018) The effects of oil prices on confidence and stock return in China, India and Russia. Quant. Financ. Econ 2: 884-903

Borremans AD, Zaychenko IM, Iliashenko OY (2018) Digital economy. IT strategy of the company development.MATEC Web of Conferences 170:01034

Busch T, Hoffmann VH (2007) Emerging carbon constraints for corporate risk management. Ecological Economics 62:518-528

Chapple L, Clarkson PM, Gold DL (2013) The cost of carbon: capital market effects of the proposed emission trading scheme (ETS). Abacus 49:1-33

Chen X, Luo Z, Wang X (2017) Impact of efficiency, investment, and competition on low carbon manufacturing. Journal of cleaner production 143:388-400
Chen X, Li Y, Xiao J, Wen F (2020) Oil shocks, competition, and corporate investment: evidence from China. Energy Economics 89: 104819

Cheng J, Liu Y (2018) The effects of public attention on the environmental performance of high-polluting firms: based on big data from web search in China. Journal of Cleaner Production 186:335-341

Cheng C, Ren X, Wang Z, Yan C (2019) Heterogeneous impacts of renewable energy and environmental patents on $\mathrm{CO} 2$ emissionEvidence from the BRIICS. Science of the total environment 668: $1328-1338$

Cheng C, Ren X, Dong K, Dong X, Wang Z (2021) How does technological innovation mitigate $\mathrm{CO} 2$ emissions in OECD countries? Heterogeneous analysis using panel quantile regression. Journal of Environmental Management 280:111818

Darko J, Aribi ZA, Uzonwanne GC (2016) Corporate governance: the impact of director and board structure, ownership structure and corporate control on the performance of listed companies on the Ghana stock exchange. Corporate Governance. 16:259-277

Destek MA, Ulucak R, Dogan E (2018) Analyzing the environmental Kuznets curve for the EU countries: the role of ecological footprint. Environmental Science and Pollution Research 25:29387-29396

Dias A, Rodrigues LL, Craig R, Neves ME (2019) Corporate social responsibility disclosure in small and medium-sized entities and large companies. Social Responsib J 15:137-154

Dogan E, Inglesi-Lotz R (2020) The impact of economic structure to the environmental Kuznets curve (EKC) hypothesis: evidence from European countries. Environmental Science and Pollution Research 27:12717-12724

Dong K, Dong X, Ren X (2020) Can expanding natural gas infrastructure mitigate $\mathrm{CO} 2$ emissions? Analysis of heterogeneous and mediation effects for China. Energy Economics 90:104830

Duan K, Ren X, Shi Y, Mishra T, Yan C (2021) The marginal impacts of energy prices on carbon price variations: evidence from a quantileon-quantile approach. Energy Economics 95:105131

Eaton S, Kostka G (2017) Central protectionism in China: the "central SOE problem" in environmental governance. The China Quarterly 231:685-704

Fan J-L, Liao H, Liang Q-M, Tatano H, Liu C-F, Wei Y-M (2013) Residential carbon emission evolutions in urban-rural divided China: an end-use and behavior analysis. Applied Energy 101: 323-332

Fan Z, Zhang Z, Zhao Y (2021) Does oil price uncertainty affect corporate leverage? Evidence from China. Energy Economics 98:105252

Fang Z, Kong X, Sensoy A, Cui X, Cheng F (2021) Government's awareness of Environmental protection and corporate green innovation: a natural experiment from the new environmental protection law in China. Economic Analysis and Policy 70:294-312

Farah T, Li J, Li Z, Shamsuddin A (2021) The non-linear effect of CSR on firms' systematic risk: International evidence. Journal of International Financial Markets, Institutions and Money 71:101288

Flammer C (2021) Corporate green bonds. Journal of Financial Economics. Forthcoming, Available at SSRN: https://ssrn.com/ abstract $=3125518$

Gill AR, Viswanathan KK, Hassan S (2018) A test of environmental Kuznets curve (EKC) for carbon emission and potential of renewable energy to reduce green house gases (GHG) in Malaysia. Environment, Development and Sustainability 20:1103-1114

Greene S, Jia H, Rubio-Domingo G (2020) Well-to-tank carbon emissions from crude oil maritime transportation. Transportation Research Part D: Transport and Environment 88:102587

Grossman GM, Krueger AB (1995) Economic growth and the environment. The quarterly journal of economics 110:353-377

Hamilton JD (2003) What is an oil shock? Journal of econometrics 113 : 363-398

Haushalter GD, Heron RA, Lie E (2002) Price uncertainty and corporate value. Journal of Corporate Finance 8:271-286 
He J, Wang H (2012) Economic structure, development policy and environmental quality: an empirical analysis of environmental Kuznets curves with Chinese municipal data. Ecological Economics 76:4959

He Z, Chen J, Zhou F, Zhang G, Wen F (2020) Oil price uncertainty and the risk-return relation in stock markets: evidence from oilimporting and oil-exporting countries. International Journal of Finance and Economics. https://doi.org/10.1002/ijfe.2206

Henriques I, Sadorsky P (2011) The effect of oil price volatility on strategic investment. Energy Economics 33:79-87

Hoffmann VH, Busch T (2008) Corporate carbon performance indicators: Carbon intensity, dependency, exposure, and risk. Journal of Industrial Ecology 12:505-520

Hu M, Tian S, Liang Y (2017) Research on environmental performance evaluation of China's sustainable investment funds based on EIOLCA model. Ecological Economy 33:106-111

Ikram M, Zhou P, Shah S, Liu G (2019) Do environmental management systems help improve corporate sustainable development? Evidence from manufacturing companies in Pakistan. Journal of Cleaner Production 226:628-641

Ilyas M, Khan A, Nadeem M, Suleman MT (2021) Economic policy uncertainty, oil price shocks and corporate investment: evidence from the oil industry. Energy Economics 97:105193

Ji J, Liu L, Ma X (2011) Greenhouse gas emissions by Chinese economy: an assessment based on EIO-LCA model. Acta Scientiarum Naturalium Universitatis Pekinensis 47:741-749

Jiang Q, Khattak SI, Rahman ZU (2021a) Measuring the simultaneous effects of electricity consumption and production on carbon dioxide emissions (CO2e) in China: new evidence from an EKC-based assessment. Energy229:120616

Jiang Y, Luo T, Wu Z, Xue X (2021b) The driving factors in the corporate proactivity of carbon emissions abatement: empirical evidence from China. Journal of Cleaner Production 288:125549

Karim AE, Albitar K, Elmarzouky M (2021) A novel measure of corporate carbon emission disclosure, the effect of capital expenditures and corporate governance. Journal of Environmental Management 290:112581

Kuo L, Yu HC (2017) Corporate political activity and environmental sustainability disclosure: the case of Chinese companies. Balt J Manag 12:348-367

Legenchuk S, Pashkevych M, Usatenko O, Driha O, Ivanenko V (2020) Securitization as an innovative refinancing mechanism and an effective asset management tool in a sustainable development environment. E3S Web of Conferences 166:13029

Li T, Wang Y, Zhao D (2016) Environmental Kuznets curve in China: new evidence from dynamic panel analysis. Energy Policy 91:138147

Li P, Zhao P, Brand C (2018) Future energy use and CO2 emissions of urban passenger transport in China: a travel behavior and urban form based approach. Applied Energy 211:820-842

Li Z, Liao G, Albitar K (2020) Does corporate environmental responsibility engagement affect firm value? The mediating role of corporate innovation. Business Strategy and the Environment 29:1045-1055

Li X, Yang Z, Li S, Huang W, Zhan J, Lin W (2021) Reservoir characteristics and effective development technology in typical lowpermeability to ultralow-permeability reservoirs of China National Petroleum Corporation. Energy Explor Exploit.https://doi.org/10. 1177/01445987211005212

Lin B, Omoju OE, Nwakeze NM, Okonkwo JU, Megbowon ET (2016) Is the environmental Kuznets curve hypothesis a sound basis for environmental policy in Africa? Journal of Cleaner Production 133: $712-724$

Liu M, Ren X, Cheng C, Wang Z (2020) The role of globalization in CO2 emissions: a semi-parametric panel data analysis for G7. Science of the Total Environment 718:137379
Luo T, Tan Y, Langston C, Xue X (2019) Mapping the knowledge roadmap of low carbon building: a scientometric analysis. Energy and Buildings 194:163-176

Maghyereh A, Abdoh H (2020) Asymmetric effects of oil price uncertainty on corporate investment. Energy Economics 86:104622

Maghyereh AI, Awartani B, Bouri E (2016) The directional volatility connectedness between crude oil and equity markets: new evidence from implied volatility indexes. Energy Economics 57:78-93

Matthews HS, Small MJ (2000) Extending the boundaries of life-cycle assessment through environmental economic input-output models. Journal of Industrial Ecology 4:7-10

Miao Z, Baležentis T, Tian Z, Shao S, Geng Y, Wu, R. (2019) Environmental performance and regulation effect of China's atmospheric pollutant emissions: evidence from "three regions and ten urban agglomerations". Environmental and Resource Economics 74:211-242

Moya-Martínez P, Ferrer-Lapeña R, Escribano-Sotos F (2014) Oil price risk in the Spanish stock market: an industry perspective. Economic Modelling 37:280-290

Musa KS (2020) Crude oil price, urbanization and environmental pollution in Nigeria: evidence from ARDL approach. Asian Journal of Economic Modelling 8:227-240

Nwani C (2017) Causal relationship between crude oil price, energy consumption and carbon dioxide (CO2) emissions in Ecuador. OPEC Energy Review 41:201-225

Ooba M, Hayashi K, Fujii M, Fujita T, Machimura T, Matsui T (2015) A long-term assessment of ecological-economic sustainability of woody biomass production in Japan. Journal of Cleaner Production 88:318-325

Park S, Song S, Lee S (2017) Corporate social responsibility and systematic risk of restaurant firms: the moderating role of geographical diversification. Tourism Management 59:610-620

Peng MW, Bruton GD, Stan CV, Huang Y (2016) Theories of the (stateowned) firm. Asia Pacific Journal of Management 33:293-317

Peng J, Song Y, Tu G, Liu Y (2021) A study of the dual-target corporate environmental behavior (DTCEB) of heavily polluting enterprises under different environment regulations: green innovation vs. pollutant emissions. Journal of Cleaner Production 297:126602

Phan DHB, Tran VT, Nguyen DT (2019) Crude oil price uncertainty and corporate investment: New global evidence. Energy Economics 77: $54-65$

Rahayu SM (2019) Mediation effects financial performance toward influences of corporate growth and assets utilization. Int J Product Perform 68:981-996

Ratti RA, Hasan MZ (2013) Oil price shocks and volatility in Australian stock returns. Economic Record 89:67-83

Ren X, Lu Z, Cheng C, Shi Y, Shen J (2019) On dynamic linkages of the state natural gas markets in the USA: evidence from an empirical spatio-temporal network quantile analysis. Energy Economics 80: 234-252

Ren X, Cheng C, Wang Z, Yan C (2021) Spillover and dynamic effects of energy transition and economic growth on carbon dioxide emissions for the European Union: a dynamic spatial panel model. Sustainable Development 29:228-242

Ritchie J, Dowlatabadi H (2014) Understanding the shadow impacts of investment and divestment decisions: adapting economic inputoutput models to calculate biophysical factors of financial returns. Ecological Economics 106:132-140

Sabbaghi O (2020) The impact of news on the volatility of ESG firms. Glob Finance J 4:100570

Saboori B, Sulaiman J, Mohd S (2012) Economic growth and CO2 emissions in Malaysia: a cointegration analysis of the environmental Kuznets curve. Energy policy 51:184-191

Sadorsky P (1999) Oil price shocks and stock market activity. Energy economics 21:449-469 
Sadorsky P (2008) Assessing the impact of oil prices on firms of different sizes: Its tough being in the middle. Energy Policy 36:3854-3861

Sari WP, Rosalina D, Ks, I. L. (2020) The impact of premium income on asset growth: a case of Indonesia Sharia Insurance. Accounting and Business Journal 2:53-60

Scherer AG, Voegtlin C (2020) Corporate governance for responsible innovation: approaches to corporate governance and their implications for sustainable development. Academy of Management Perspectives 34:182-208

Shen H, Huang N (2019) 2019. Can carbon emission trading mechanism improve enterprise value [J]. Finance and Trade Economics 40(01): 144-161

Shen L, Wu Y, Lou Y, Zeng D, Shuai C, Song X (2018) What drives the carbon emission in the Chinese cities? - a case of pilot low carbon city of Beijing. Journal of Cleaner Production 174:343-354

Song L (2018) State-owned enterprise reform in China: past, present and prospects. China's 40 Years of Reform and Development: 19782018, pp 345-373

Sun Y, Li M, Zhang M, Khan HSUD, Li J, Li Z, Sun H, Zhu Y, Anaba OA (2021) A study on China's economic growth, green energy technology, and carbon emissions based on the Kuznets curve (EKC). Environmental Science and Pollution Research 28:72007211

Tang DY, Zhang Y (2020) Do shareholders benefit from green bonds? Journal of Corporate Finance 61:101427

Ting P-H (2021) Do large firms just talk corporate social responsibility?the evidence from CSR report disclosure. Finance Research Letters 38:101476

van Tulder R (2018) Business \& the Sustainable Development Goals: a framework for effective corporate involvement. Erasmus University, Rotterdam

Wang Y, Xiang E, Ruan W, Hu, W. (2017a) International oil price uncertainty and corporate investment: evidence from China's emerging and transition economy. Energy Economics 61:330-339

Wang Y, Zhang C, Lu A, Li L, He Y, Tojo J, Zhu X (2017b) A disaggregated analysis of the environmental Kuznets curve for industrial CO2 emissions in China. Applied Energy 190:172-180

Wang F, Sun J, Liu YS (2019) Institutional pressure, ultimate ownership, and corporate carbon reduction engagement: evidence from China. Journal of Business Research 104:14-26

Wei P, Shu H (2021) Evaluation of carbon performance of stock portfolio: an analysis based on the EIO-LCA method. Manag Rev 33:24 39

Xiao J, Zhou M, Wen F, Wen F (2018) Asymmetric impacts of oil price uncertainty on Chinese stock returns under different market conditions: Evidence from oil volatility index. Energy Economics 74:777-786

Yan D, Kong Y, Ren X, Shi Y, Chiang S (2019) The determinants of urban sustainability in Chinese resource-based cities: a panel quantile regression approach. Science of the total environment 686:1210-1219

Yan D, Ren X, Kong Y, Ye B, Liao Z (2020) The heterogeneous effects of socioeconomic determinants on PM2. 5 concentrations using a two-step panel quantile regression. Applied Energy 272:115246

Yoon KH, Ratti RA (2011) Energy price uncertainty, energy intensity and firm investment. Energy Economics 33:67-78

Yorbana SG (2016) Local issues of Chinese direct investment in Africa: the case of China national petroleum corporation international Chad (2006-2013). The Challenge of BRIC Multinationals, pp 629-652

Yu W, Yang L, Xiao MH (2017) Comparative research on the structure of Chinese carbon emissions between 2007 and 2012 based on EIOLCA method. Ecol Econ 33:21-25

Zhang B, Wang B, Wang Z (2017) Role of renewable energy and nonrenewable energy consumption on EKC: evidence from Pakistan. Journal of Cleaner Production 156:855-864

Zhang Y, Chen X, Wu Y, Shuai C, Shen L (2019a) The environmental Kuznets curve of $\mathrm{CO} 2$ emissions in the manufacturing and construction industries: a global empirical analysis. Environmental Impact Assessment Review 79:106303

Zhang Y, Yan D, Hu S, Guo S (2019b) Modelling of energy consumption and carbon emission from the building construction sector in China, a process-based LCA approach. Energy Policy 134:110949

Zhang J, Jin W, Philbin SP, Lu Q-C, Ballesteros-Pérez P, Skitmore M, Li $H$ (2021) Impact of environmental regulations on carbon emissions of transportation infrastructure: China's evidence. Cleaner and Responsible Consumption 2:100010

Zhao J, Zhao Z, Zhang H (2019) The impact of growth, energy and financial development on environmental pollution in China: new evidence from a spatial econometric analysis. Energy Econ 93: 104506

Zinina O, Olentsova, J (2020) Evaluating the effectiveness of company development in processing industry. E3S Web of Conferences 161: 01074

Zou X (2018) VECM model analysis of carbon emissions, GDP, and international crude oil prices. Discrete Dyn Nat Soc 2018:1-11

Publisher's note Springer Nature remains neutral with regard to jurisdictional claims in published maps and institutional affiliations. 